ROCZNIKI HUMANISTYCZNE

Tom LXVIII, zeszyt 7 - 2020

DOI: http://dx.doi.org/10.18290/rh20687-3

ARTIOM STEPANOV

\title{
ФУНКЦИОНИРОВАНИЕ ТРАДИЦИОННЫХ СКАЗОЧНЫХ ОБРАЗОВ В ПРОЗЕ ВИКТОРА АСТАФЬЕВА И ВАЛЕНТИНА РАСПУТИНА
}

Русская народная сказка является неисчерпаемым источником вдохновения для многих писателей, художников, композиторов. Многие художники слова обращаются к народной сказке не только как к сокровищнице оригинальных поэтических приемов, но и заимствуют традиционные сказочные образы. Поэтому не случайно в художественной литературе народная сказка обретает новую жизнь в форме литературной сказки. С другой стороны, сказочная поэтика используется Федором Абрамовым, Василием Беловым, Василием Шукшиным в своих несказочных художественных произведениях. Все это вместе взятое получило определение как сказочная традиция, явление многогранное, определяющее специфику и направление отечественного литературного процесса.

В 60-е годы ХХ века в художественной литературе выделяется особое направление, получившее название “деревенская проза", представителями которой стали Ф.А. Абрамов, Б.А. Можаев, В.И. Белов, В.Г. Распутин, В.П. Астафьев. Писатели-деревенщики показали и опоэтизировали человека “земного в деяниях и помыслах" (Астафьев 319). Само название “деревенская проза” указывает на особый хронотоп: основные события в назван-

АРТЁМ СЕРГЕЕВИч СТЕПАНОВ - Нижегородский государственный педагогический университет им. К. Минина (Мининский университет), Факультет гуманитарных наук, Кафедра русской и зарубежной филологии, преподаватель, докторант; адрес для корреспонденции: 603950, Нижегородская область, Нижний Новгород, ул. Ульянова 1, ауд. 406; e-mail: artemstep123@yandex.ru. ORCID: https://orcid.org/0000-0002-3786-6663.

Artyom Sergeevich StePANOv - Nizhny Novgorod State Pedagogical University (Minin University), Faculty of Humanities, Department of Russian and Foreign Philology, lecturer, PhD student; address for correspondence: 603950, Нижегородская область, Нижний Новгород, ул. Ульянова 1, ауд. 406; e-mail: artemstep123@yandex.ru. https://orcid.org/ORCID: 0000-00023786-6663. 
ных произведениях происходят в деревенском доме или на подворье, а жизненное пространство человека ограничено родной деревней. Оппозиция “город VS деревня" несет вполне отчетливую функцию: показать враждебность городской среды для традиционного крестьянства, тем самым подчеркнуть агрессивность новой цивилизации. В целом литературное направление “деревенская проза" обладает высоким уровнем онтологичности: обращение к вечным проблемам бытия, поиск смысла жизни и проблема постановки цели земного пути. Обоснованность аналитического сопоставления творчества В.П. Астафьева и В.Г. Распутина в рамках данной статьи исходит из заключенной в них авторской концепции мира и жизни человека в нем. Обоих писателей остро беспокоит вопрос утраты русским человеком извечных традиционных духовных основ. Писатели, анализируя современную им действительность, подводят читателя к философскому осмыслению мира, в котором все: и быт людей, и культура народа, и национально-религиозные истоки имеют одно начало. Разрушение одного из данных жизненных направлений ведет к крушению всего мира. Поэтому их герои так одиноки и неустроенны в таком пустом мире. В.Астафьев и В.Распутин объединены типологической общностью в изображении человека, его бытия. Художественный вердикт писателей един: нет человека без общества, общества, отделенного от самого мира, государства без людей. По мнению писателей, человек обязан находиться всегда на пересечении и соединении данных начал, которые должны гармонично располагаться по отношению друг к другу. Приверженность русского человека сложившимся традициям В. Астафьев и В. Распутин показывают через обращение к устному народному творчеству, поэтому основная цель статьи заключается в выявлении специфики функционирования традиционных сказочных образов в прозе Астафьева и Распутина.

Рассказ Царь-рыба (1976) является центральным в одноименной повести, обозначенной В.П. Астафьевым как повествование в рассказах. Вслед за выходом появилось множество исследований и критических статей. Например, П.А. Гончаров писал, что проблема взаимоотношений человека и природы «нигде не получала такого яркого, глубокого и оригинального решения, как в повествовании в рассказах Царь-рыба (Гончаров 205). Наум Лейдерман видит в Царь-рыбе концепцию единства всего сущего, реализованного через принцип ассоциаций между человеком и природой (Лейдерман 13). С натурфилософской точки зрения смотрит на Царь-рыбу А.И. Смирнова. Исследовательница утверждает, что писатель занят поиском места человека в природе, создавая своего рода натурфилософский манифест (Смирнова 38-42). Иссле- 
довательская мысль находит истоки рассказа Царь-рыба и в романе Моби-дик Г. Мелвилла и Старик и море Э. Хемингуэя (Дегтярева).

Однако считаем научно обоснованной и продуктивной попытку сопоставить творчество Астафьева и с фольклорными текстами. В своей работе, посвященной творчеству названного писателя, Т.М. Вахитова предполагала, что в образе царь-рыбы ощущается «древний фольклорный слой, связанный с русскими сказками и преданиями о могучей рыбе» (Вахитова 42). Особо следует отметить сказочные сюжеты, в которой золотая рыбка наделена волшебными свойствами: это и Сказка о золотой рыбке Александра Пушкина, фольклорные истоки которой доказаны во многих работах (Бонди 1971; Азадовский 1936 и др.), Сказка о рыбаке и его жене братьев Гримм, сказка Золотая рыбка из сборника Афанасьева (Аф. I, 75).

Традиционные сказочные зачины начинаются с введения в условный сказочный хронотоп: «в некотором царстве, в некотором государстве», «жилбыл царь» и т.д. В. Астафьев не начинает свой рассказ сказочным зачином, однако в самом названии упоминает «царя», непременным атрибутом которого является царство. Таким «царством» для царь-рыбы является река.

Мифопоэтический образ рыбы мы встречаем в литературной сказке Петра Ершова Конек-Горбунок: «Чудо-юдо рыба-кит. / Все бока его изрыты, / Частоколы в рёбра вбиты, / На хвосте сыр-бор шумит, / На спине село стоит〉 (Ершов 125).

Описание рыбы у Астафьева менее поэтично: «червячные усы, висящие под ровно состругнутой внизу головой», «перепончатый, крылатый хвост на доисторического ящера походила рыбина» (Астафьев 139). Кроме того, вместо «ершовского» частокола у Астафьева в кожу царь-рыбы вонзены рыболовные крючки.

Отличия рыбы в сказке Ершова и в рассказе Астафьева в том, что у Ершова «рыба-кит» прикована к одному месту в наказание за проглоченные корабли, а у Астафьева наоборот: рыбак оказывается повязанным рыболовными снастями с «царь-рыбой». У обоих авторов освобождение рыбы происходит в обмен на свободу и жизнь человека.

Ни разу Астафьев не называет вид рыбы. Вместо прямого названия «осетр» дается сказочно-поэтическое «царь-рыба». Царь применительно к животным означает верхнюю ступень иерархической лестницы.

Сам образ «царь-рыбы» познается читателем через суеверные представления рыбаков. Игнатьич, зажиточный человек в селе, опытный рыбак, еще от своего деда «много всякой всячины наслушался про царь-рыбу, хотел ее, богоданную, сказочную увидеть, изловить, но робел» (Астафьев 144). В то 
же время дед предупреждал внука, что «лучше отпустить ее, незаметно так, нечаянно будто отпустить...» (Астафьев 144). Вспомнив структурную особенность волшебной сказки, а именно, формулу «запрет - нарушение запрета», налицо как раз нарушение Игнатьичем наставления своего деда - отпустить царь-рыбу. Ведь вначале браконьер Игнатьич, помня о запрете, не желает расставаться с рыбой. Все успехи Игнатьича рыбаки объясняют тем, что он «слово знает!» Александр Афанасьев в книге Поэтические воззрения славян на природу писал, что все поэтическое творчество развилось из древнейших мифов (Афанасьев). Такого же мнения придерживался и Ф.И. Буслаев, относящий суеверие к одному из существующих видов поэзии (Буслаев 61). Суеверное сознание рыбаков в Царь-рыбе становится важным предметом изображения.

Астафьев использует сказочную традицию не только, заимствуя традиционные фольклорные образы, но и умело вводя сказочную поэтику в словесную ткань произведения. Это и постоянные эпитеты: «бутончик маковый», «яичко голубиное», «умница-разумница». Явно фольклорного происхождения дедов заговор, учивший внука сечь рыбу прутом и приговаривать: «Пошли тятю, пошли маму, пошли тетку, пошли дядю, пошли дядину жану!» (Астафьев 148).

Подводя итог проведенному анализу, можно сказать, что Астафьев ориентируется на устное народное творчество при создании образов, прослеживается связь с фольклором и в сюжетообразующих мотивах рассказа. Открытый хронотоп рассказа приближен к сказочному. Изображая Сибирь, В.П. Астафьев внимателен даже к самым древним языческим пластам народной культуры, использует важнейшую структурную особенность сказки - «запрет», «нарушение запрета». Нарушение запрета становится началом осложнения приключений странствующего героя. Известно, что первоначально многие этические нормы существовали в виде немотивированных запретов, если этот запрет нарушается, то рушатся и прежние устои, связь с традицией безвозвратно утрачивается.

То же самое можно сказать и о творчестве В. Распутина. Его творчеству посвящено множество статей и монографий (Новожеева; Ма Сяоди; Сирин; Зубкова; Каминский). Повесть Прощание с Матёрой по праву считается одним из самых значительных произведений «деревенской прозы». Повесть во многом автобиографична: Матёра похожа на родную деревню писателя Аталанку, оказавшуюся под водой. Сам Распутин признавался: «Эта повесть в определенном смысле для меня - рубеж в писательской работе» (Распутин). Можно добавить, что произведение подводит итог исканиям «деревен- 
ской прозы», здесь прерывается традиция поиска земли обетованной в пространстве географическом, поиск перемещается в ирреальные пределы.

По-разному относятся персонажи повести к предстоящему затоплению острова. Например, Настасья откровенно тоскует: «Кто ж старое дерево пересаживает?» (Распутин 387). Недавно живущей на острове Симе и того хуже, у нее нет родственников и ей остается одна дорога - в дом престарелых. Дарья крепится, недаром образ Дарьи - философский эпицентр, от которого в немалой степени зависит окружающее. Богодул воспринимается как своеобразный дух Матёры, ее хранитель. И.А. Панкеев считает образ Богодула как раз «тем звеном, которое наиболее явно демонстрирует связь природы с человеком» (Панкеев 88). Это утверждение справедливо, ведь реальное в этой повести именно потому кажется реальным, что оттенено фантастическими (или сказочными) образами. Именно Богодул возвестил, что «мер-ртвых гр-рабют!», призвав население к активным действиям.

Кладбище - один из значимых образов в русской литературе. Кладбище как пространство статической гармонии, печали и грусти, осознания смерти как великого таинства природы встречается и у Пушкина в Евгении Онегине, и у Тургенева в Отцах и детяx, и у Гончарова в Обломове, и в рассказе Чехова Ионыч, и в творчестве других писателей. Это пространство в повести Прощяание с Матёрой грубейшим образом нарушается. В третьей главе повести показано разное отношение к одному и тому же месту: то, что для одних свято, для других буднично. Жители деревни застали работников санэпидемстанции за тем, как те уже «стаскивали спиленные тумбочки, оградки и кресты в кучу, чтобы сжечь их одним огнём» (Распутин 387). Они и не подозревают, что для Дарьи и ее односельчан кладбище - нечто святое, самый крепкий узел, который связывает их с этим родным местом. Даже рассудительная Дарья не выдержала и, «задыхаясь от страха и ярости, закричала» на губителей памяти.

Использование архетипических фольклорных образов начинается с первых строк повести. Главные герои повести воспринимают свой остров, как центр вселенной. Наделяют его наилучшими качествами: изобилием, красотой, самодостаточностью: «Остров растянулся на пять с лишним верст, и не узенькой лентой, а утюгом, - было, где разместиться и пашне, и лесу, и болоту с лягушкой, а с нижней стороны за мелкой кривой протокой к Матёре близко подчаливал другой остров, который называли то Подмогой, то Подногой. Подмогой - понятно: чего не хватало на своей земле, брали здесь...» (Распутин 172).

В мире Матёры есть «своя церквушка, как и положено на высоком и чистом месте, и «мельница на верхней проточке, специально будто для не про- 
рытой, с помолом хоть и некорыстным, да незаемным, на свой хлебушко хватало», и свое кладбище, и священное дерево, и место для игрищ - роща. Возникает такая своеобразная мифопоэтическая модель мира - Матёра. «Но от края до края, от берега до берега хватало в ней и раздолья, и богатства, и дикости, и всякой твари по паре - всего, отделившись от материка, держала она в достатке, не потому ли и назвалась громким именем Матёра?» (Распутин 172). Представление о «замкнутом, локализованном универсуме» (Гуревич 288) свойственно архаичному мифологическому мышлению, не вычленяющему человека из природы, окружающего мира. Матёринские старухи считают жизнь на острове праведной, ибо она течет по известно установленному порядку, в гармонии с большим миром, неторопливо и по совести: «Раньше совесть сильно различали. Ежели кто норовил без нее, сразу заметно, все друг у дружки на виду жили» (Распутин 195).

На противопоставлении праведности и греховности выстраивается пространственная модель мира в повести Прощание с Матёрой. Замкнутый мирок Матеры от остального мира отделен рекой-границей, потому что этот мир в восприятии героинь чужой, непонятный, диковинный, греховный. Таков город в воспоминаниях Дарьи: «Я у дочери в городе-то гостевала - дивля... А что чудней, что баня и уборна, как у нехристей, в одном закутке, возле кухоньки»; и ответы Настасьи в этом диалоге: «Я там одну неделю с тоски помру. Посередь чужих-то. Кто же старое дерево пересаживает?!» (Распутин 178). Обратим внимание, что Распутин наделяет свою пространственную модель «характерной способностью мифологического пространства моделировать иные, непространственные (семантические, ценностные) отношения〉 (Лотман, Успенский 146).

Пространство Матёры организуется и как характеристика земного рая, и, кроме этого, представляет собой модель Вселенной, ведь в повести изображена глобальная ситуация - кончина всего сущего мира. Юрий Селезнёв считает Матёру материком, окружённым со всех сторон океаном, уменьшенной моделью мира (Селезнёв 40).

Ни в чем не виноватая Матёра рушится, покосились заборы, неухоженными стали огороды, но среди пожаров, вырубок сохраняется стержневое, прочное и фундаментальное, дающее надежду, что Матера не погибнет, это - «царский листвень», которому отведена целая глава в повести. Многие истории и легенды связаны с ним, «неизвестно, с каких пор жило поверье, что как раз им, «царским лиственем», и крепится остров к речному дну, одной общей земле, и покуда стоять будет он, будет стоять и Матёра» гласит одно из преданий (Распутин 490). Но вот и до «стража» острова добрались чужие 
люди, которым приказано подготовить ложе водохранилища. Бессильны оказались рабочие, подготавливающие остров к затоплению. Три раза, как и в сказке, подбираются они к лиственю с прибаутками. «Царский листвень» устоял против мужиков с их техническими новинками. Мужики за эту нерушимость сравнивают его с Богодулом: «Такой же ненормальный» (Распутин 386). Параллель можно провести и между лиственем и старухой Дарьей - внутренне крепкой, нежелающей променять вечное на временное.

Особую остроту столкновения «конечности» и «нескончаемости» в последнем лете Матёры придает сказочная соотнесенность этого острова с Буян-островом и, соответственно, образом рая. Сами матёринцы обнаруживают связь своего острова со сказочным островом-Буяном: «На море-окияне, на острове Буяне...» - некстати вспомнилась Дарье старая и жуткая заговорная молитва...» (Распутин 345). Остров Буян - место вечной жизни, вечной весны или лета, на острове Буяне лето не кончается.

Сцена прощания Дарьи со своей избой проникнута драматизмом. Доносящийся откуда-то издалека голос спрашивает Дарью, прибрала ли она избу, как проводит она её в последний путь? Известно, что умерших перед положением во гроб омывают. Так же и старуха Дарья свою избу как перед погребением омывает: белит печь и потолок, выскабливает пол, моет окна, вешает новые занавески. Поджигателям не понять её действия, но для Дарьи её жилище - живое существо, и она обязана проводить избу в последний путь по всем правилам.

Своеобразным продолжением повести Прощяание с Матёрой является повесть Пожар, впервые опубликованная в журнале «Наш современник», № 7 за 1985 год, повесть была удостоена Государственной премии СССР. Преемственность двух повестей подчеркнута в самих произведениях: дядя Миша Хампо напоминает Богодула, а сама Сосновка - тот самый новый поселок с безликим названием, в который должны переехать матёринцы.

Единственный резко очерченный женский образ в повести - Алёна, жена Ивана Петровича Егорова. Этот образ важен для автора, так как с первых страниц до конца повести Распутин постоянно привлекает к нему внимание читателя. В этой женщине воплощено все лучшее, она умеет прожить жизнь в ладу с собой, видит смысл жизни только в работе, в семье, в заботах о близких; Алёна не говорит, а делает. Вспомнив лучшие женские фольклорные образы русских народных сказок, можно предположить, что жена Егорова - это те самые Алёнушки, удачно вышедшие замуж дочери, только вне сказки. Алёна и Иван Петрович прожили на момент описываемых событий тридцать два года, вырастили детей и продолжают любить друг друга: «Алена для Ивана 
Петровича была больше, чем жена. В этой маленькой расторопной фигуре, как во всеединой троице, сошлось всё, чем может быть женщина» (Распутин 518).

В повестях В. Распутина русские женщины напоминают лучших сказочных героинь, в которых просматриваются черты народного характера: старухи Анна и Дарья, Мария, Настена. Они сохраняют связь с древними обычаями, прочно связаны с миром природы, с землей. Истоки этих образов следует искать в фольклоре.

Проанализировав функционирование традиционных сказочных образов в рассказах В. Астафьева и В. Распутина, можно утверждать, что писатели используют сказочную традицию в аспекте включения в повествование традиционных сказочных образов, организуют свои произведения с опорой на традиционные фольклорные смыслы. В.Г. Распутин активнее, чем другие писатели, использует сказочные образы и сказочную поэтику. Любимые Распутиным женские образы, становятся привлекательными и запоминающимися благодаря зеркальному отражению, сказочных бликов, которые падают на них от героинь русских народных сказок. В.П. Астафьев выстраивает систему персонажей с опорой на фольклорную традицию, используя, в частности, мотив троекратного повторения, мифологический рассказ о том, как царь-рыба предпочла Игнатьичу «грузного, силой налитого Енисея» (Астафьев 163) в повести Царь-рыба.

Среди всех деревенских прозаиков Распутин, пожалуй, наименее лиричен, ему всегда, как прирожденному публицисту, больше удавались нахождение и постановка проблемы, чем воплощение ее в художественной форме. Творчество Виктора Астафьева не умещается в рамки деревенской прозы: военная тема также очень важна для него. Однако именно Астафьев подвел горький итог деревенской прозе: «Мы отпели последний плач - человек пятнадцать нашлось плакальщиков о бывшей деревне. Мы и воспевали ее одновременно. Как говорится, восплакали хорошо, на достойном уровне, достойном нашей истории, нашей деревни, нашего крестьянства. Но это кончилось» (Кувалдин 336).

\section{БИБЛИОГРАФИЯ}

Азадовский, Марк. Литература и фольклор. Художественная литература, 1938 [Azadovskiy, Mark. Literatura i fol'klor. Hudozhestvennaya literatura, 1938].

Астафьев, Виктор. Сочинения в 2 томах, т. 1. У-Фактория, 2003 [Astafiev, Viktor. Sochineniya $v$ tomakh, t. 1. U-Faktoriya, 2003].

Астафьев, Виктор. Царь-рыба: Повествование в рассказах. Молодая гвардия, 1984 [Astafiev, Viktor. Car'-ryba: Povestvovaniye v rasskazakh. Molodaya gvardiya, 1984]. 
Афанасьев, Александр. Древо жизни. Избранные статьи. Современник, 1982 [Afanasiev, Aleksandr. Drevo zhizni. Izbrannyye stat'i. Sovremennik, 1982].

Бонди, Сергей. Черновики Пушкина. Просвещение, 1971 [Bondi, Sergey. Chernoviki Pushkina. Prosveshcheniye, 1971].

Буслаев, Фёдор. “О народной поэзии в древнерусской литературе”. О литературе: Исследования, Статьи. Государственное издательство "Художественная литература", 1990 [Buslaev, Fyodor. "O narodnoy poezii v drevnerusskoy literature". O literature: Issledovaniya, stat'i. Gosudarstvennoye izdatel'stvo "Khudozhestvennaya literatura", 1990].

Гончаров, Петр. Творчество В.П. Астафьева в контексте русской прозы второй половины XX века: Дис. докт. филол. наук. Тамбов, 2004 [Goncharov, Petr. Tvorchestvo V.P. Astaf'yeva v kontekste russkoy prozy vtoroy poloviny XX veka. Dissertation. Tambov, 2004].

Дегтярева, Вера. «Царь-рыба» В.П.Астафьева - «Моби Дик» Г. Мелвилла - «Старик и море» Э. Хемингуэя: к вопросу о типологической общности произведений [Degtyareva, Vera. «Car'-ryba» V.P.Astafieva - «Mobi Dik» G. Melvilla - «Starik i more» E. Hemingueya: $\mathrm{k}$ voprosu o tipologicheskoy obshchnosti proizvedeniy], veradegtjarjova. narod.ru/article4.htm. Accessed 15 May 2020.

Ершов, Пётр. “Конек-Горбунок”. Сказки русских писателей. Детская литература, 1985 [Ershov, Pyotr. “Konek-Gorbunok". Skazki russkih pisatelej. Detskaya literatura, 1985].

Зубкова, Людмила. Русское имя второй половины ХХ века в лингвокультурологическом аспекте (по произведениям Ф. Абрамова, В. Астафьева, В. Распутина и В. Шукиина). Издательство Воронеж, гос. ун-та, 2008 [Zubkova, Lyudmila. Russkoye imya vtoroy poloviny $\mathrm{XX}$ veka $\mathrm{v}$ lingvo-kul'turologicheskom aspekte (po proizvedeniyam $\mathrm{F}$. Abramova, V. Astafieva, V. Rasputina i V. Shukshina). Izdatel'stvo Voronezh, gos. un-ta, 2008].

Каминский, Петр. «Время и бремя тревог». Публицистика Валентина Распутина. Флинта-Наука, 2012 [Kaminskiy, Petr. «Vremya i bremya trevog». Publicistika Valentina Rasputina. Flinta-Nauka, 2012].

Кувалдин, Юрий. Собрание сочинений в десяти томах, т. 10. Книжный сад, 2006 [Kuvaldin, Yuriy. Sobranie sochinenij v desyati tomah, t. 10. Knizhnyj sad, 2006].

Лейдерман, Наум. Крик сердиа. Творческий облик Виктора Астафьева. Издательство АМБ, 2001 [Leyderman, Naum. Krik serdca. Tvorcheskiy oblik Viktora Astaf'eva. Izdatel'stvo AMB, 2001].

Лотман, Юрий, и Борис Успенский. "Миф - имя - культура". Труды по знаковым системам, 1973, сc. 282-303 [Lotman, Yuriy, i Boris Uspenskiy. "Mif - imya - kul'tura". Trudy po znakovym sistemam, 1973, ss. 282-303].

Ма Сяоди. Проблема национального самосознания в творчестве В. Г. Распутина. Дисс. канд. филолог. наук, Московский Государственный университет имени М.В. Ломоносова, 2015 [Ma Syaodi. Problema nacional'nogo samosoznaniya v tvorchestve $V$. G. Rasputina. Diss. kand. filolog. nauk, Moskovskiy Gosudarstvennyy universitet imeni M.V. Lomonosova, 2015].

Новожеева, Инна. Кониепиия человека в деревенской прозе 1960-1980-х годов по произведениям В. Астафьева, Ф. Абрамова, В. Белова, В. Распутина, В. Шукиина. Дисс. канд. филолог. наук, ГОУ ВПО «Брянский государственный университет имени академика И.Г. Петровского», 2007 [Novozheeva, Inna. Konceptsiya cheloveka $v$ derevenskoy proze 1960-1980-kh godov po proizvedeniyam V. Astaf'eva, F. Abramova, V. Belova, V. Rasputina, V. Shukshina. Diss. kand. filolog. Nauk, GOU VPO «Bryanskiy gosudarstvennyy universitet imeni akademika I.G. Petrovskogo», 2007]. 
Панкеев, Иван. Валентин Распутин: По страницам произведений. Просвещение, 1990 [Pankeev, Ivan. Valentin Rasputin: Po stranitsam proizvedeniy. Prosveshcheniye, 1990].

Распутин, Валентин. "Не мог не проститься с Матёрой“. Литературная Газета, 1977, 16 марта [Rasputin, Valentin. "Ne mog ne prostit'sya s Matyoroy”. Literaturnaya Gazeta, 1977, 16 marta].

Распутин, Валентин. Прощзание с Матёрой: повести. Азбука, Азбука-Атютикус, 2015 [Rasputin, Valentin. Proshchaniye s Matëroy: povesti. Azbuka, Azbuka-Atyutikus, 2015].

Селезнёв, Юрий. В мире Достоевского. Слово живое и мертвое. “Алгоритм”, 2014. [Seleznyov, Yuriy. V mire Dostoyevskogo. Slovo zhivoye i mertvoye. "Algoritm”, 2014].

Сирин, Анатолий. Свет распутинской прозы. Издатель Сапронов Г. К., 2007 [Sirin, Anatoliy. Svet rasputinskoy prozy. Izdatel' Sapronov G. K., 2007].

Смирнова, Альфия. Русская натурфилософская проза второй половины ХХ века. ФлинтаНаука, 2009. [Smirnova, Al'fiya. Russkaya naturfilosofskaya proza vtoroy poloviny XX veka. Flinta-Nauka, 2009].

TRADYCYJNE OBRAZY BAJKOWE

W PROZIE WIKTORA ASTAFIEWA I WALENTYNA RASPUTINA

$$
\text { Streszczenie }
$$

Głównym celem artykułu jest ukazanie specyfiki funkcjonowania tradycyjnych obrazów bajkowych w prozie Wiktora Astafiewa i Walentyna Rasputina. Tradycjonalizm pisarzy, przedstawienie w ich utworach życia wewnętrznego bohaterów, otoczenia i środowiska społecznego człowieka rosyjskiego postrzegane jest w artykule poprzez odniesienia do ustnej twórczości ludowej. Autorzy umiejętnie i niejako organicznie wykorzystują obrazy mitooetyckie i folklorystyczne. Walentyn Rasputin częściej niż inni pisarze odwołuje się do motywów bajkowych i poetyki bajki. Wiktor Astafiew z kolei buduje system postaci, opierając się na tradycji ludowej, szczególnie wykorzystuje chwyt trzykrotnego powtórzenia i narrację mitologiczną.

Słowa kluczowe: ludowa bajka rosyjska; obraz bajkowy; tradycja bajkowa; proza wiejska; poetyka bajkowa; opowieść.

\section{THE FUNCTIONING OF TRADITIONAL FAIRY-TALE IMAGES IN THE PROSE OF VIKTOR ASTAFIEV AND VALENTIN RASPUTIN}

\section{S u m m a ry}

The main purpose of this article is to identify the type of the functioning of traditional fairy-tale images in the prose of Astafiev and Rasputin. In the appeal to oral folk art we can see the traditional character of writers and their typological proximity in the image of the inner world of the Russian person, their being, environment and social environment. The authors skilfully and organically include mythopoetic and folkloric images. Rasputin uses fairy-tale images and fairy-tale poetics more actively than other writers, whilst Astafiev builds a system of characters based on the folkloric tradition, using, in particular, the motif of triple repetition and the mythological story.

Key words: Russian folk tale; fairy-tale image; fairy-tale tradition; village prose; fairy-tale poetics; story. 